\title{
I welcomed the inane chatter during a procedure
}

\author{
Rhiannon De Wreede recalls the importance of inane chatter and encouragement while going \\ through an uncomfortable procedure
}

\author{
Rhiannon De Wreede
}

I have just had my coil changed. The first one was fitted five years ago and because of a routine smear the "mystery of the missing threads" was discovered. After several attempts from healthcare professionals to find them and some ultrasound scans the problem was still unresolved. So, I booked an appointment at a sexual health clinic to have the coil removed. I was nervous and didn't know what to expect.

Entering the office, we had small talk about how my "womb was on the big side." I translated this new knowledge of my body into my own words-I now had a "cavernous uterus." They reassured me that this didn't mean anything, other than the doctor might have to "roam around a bit." With my nether regions exposed and legs akimbo the procedure began. The health professional next to me was doing a fantastic job, holding my hand and talking incessantly. I needed this.

\section{Talk about anything else}

During the procedure they checked-did I need more anaesthetic? In between sweating, panting, and wincing I said, "Yes please." Trying to remain polite despite my discomfort. On the outside we are discussing my girl's name "Yes we called our girl Dylan. It is unusual" I can hear myself saying. At the same time, all I am thinking on the inside is "Where are those threads? What are they doing? When will this be over?" We continue talking about anything else, including my luck at finding a parking space.

The health professional asked "Do you want to take your jumper off?" We hauled my ridiculously thick jumper over my head without disturbing the business end. "Little bit more anaesthetic?" they asked. We've come this far I thought "Go on then." I think the conversation was on Christmas at this point, it was difficult to keep track. It could have been on space abductions for all I cared. But it was there and that's what mattered.

\section{In it together}

They continued with no luck. Leaning back the clinician looked up at me from between my legs. I wondered if she was trying not to show her frustration. They asked whether I wanted to stop the procedure- "I'll book you in for removal under general anaesthetic?" The idea had merit. But in that moment, all I could see was the saga stretching out and I wanted it over, today. I asked them to give me a minute and then to try again. Both healthcare professionals supplied a constant stream of encouragement, which helped me to find the strength to go on.

I like to think we all breathed deeply, another rummage for minute or so and ... victory. The health team high fived me and we held a mini celebration, well half of me did, my legs were still spread. "Shall I pop the other one in now?" I'd forgotten about that part. I agreed and barely felt a thing. We had won.

\section{Distraction and relaxant}

Recovery involved letting my legs down and lying there chatting about more stuff that didn't matter but was very important. I took the tea offered and sat in the waiting room willing the pain relief to work. What did I make of the whole thing? It was certainly an experience. Could I have done without it? Yes, of course. But now I can go another 5 years without worrying about it . . . every cloud. The conversations we had were a vital part of the experience, as a distraction and as a relaxant. The babble of usual topics in an unusual situation relaxed me and made the whole thing much easier.

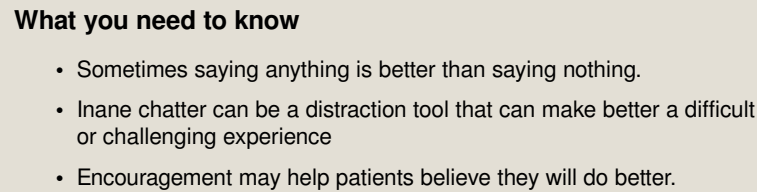




\section{Education into practice}

- What do you typically say or do to help people through uncomfortable procedures?

- How and why might you modify your approach?

- How does conversation differ, depending on whether you are alone, or have someone to assist you?

These questions were developed by the editors and reviewed by the patient author

\section{Competing interestsNone.}

Provenance and peer review: Commissioned, based on an idea from the author; not externally peer reviewed.

Published by the BMJ Publishing Group Limited. For permission to use (where not already granted under a licence) please go to http://group.bmj.com/group/rights-licensing/ permissions 